\section{Trekk artiklene}

I Tidsskriftet nr. 4/2013 presenteres en kasuistikk fra Sykehuset Østfold, Fredrikstad med konklusjon flåttbåren meningoencefalitt (TBE) hos en tenåring (1). Det er også en kommentartikkel fra nevrologer som underbygger konklusjonen (2). I Tidsskrift nr. 8/2013 kommer et kritisk spørsmål til diagnostikken (3). I supplerende brev bekreftes at diagnosen ikke var holdbar $(4,5)$.

Tilfellet dreide seg etter alt å dømme om en uvanlig akutt og dramatisk forløpende nevroborreliose. I alle fall er ingen annen diagnose sterkere sannsynliggjort. Det ble gitt ceftriakson intravenøst, og trolig har dette vært virksomt. At bedringen ikke inntrådte umiddelbart er intet motbevis mot nevroborreliose, heller ikke negativ borreliaserologi i innledende fase. I tillegg til at infusjoner med for eksempel Kiovig kan volde problemer for diagnostikken er det flere eiendommeligheter i det kliniske bildet som tilsier at dette ikke er flåttbåren meningoencefalitt. I kommentarartikkelen nevner man ikke disse: ingen feberreaksjon under forløpet, null CRP, ingen nakkestivhet med et celletall i nivå 300-400 i spinalvæsken, hvilket passer godt med nevroborreliose, men dårligere med andre infeksjoner.

Jeg bebreider ikke forfatterne av primærartikkelen. De har gitt sin ærlige presentasjon og vurdering. I Tidsskriftet har det derimot sviktet i kvalitetssikringen. Publisering av hovedartikkel og kommentarartikkel som «Noe å lære av» er dessverre en gedigen fadese som bør oppfattes som pinlig av redaktøren. Det er kun en måte å rette opp dette på: Trekk artiklene!

\section{Per Bjark}

bjap@ous-hf.no

Per Bjark (f. 1938) er spesialist i infeksjonssykdommer.

Ingen oppgitte interessekonflikter.

\section{Litteratur}

1. Gauer K, Helgestad KI, Wirsching $C$ et al. En tenåring med smerter, dobbeltsyn og ustø gange. Tidsskr Nor Legeforen 2013; 133: 422-5.

2. Ljøstad U, Mygland Å. Et virus på fremmarsj. Tidsskr Nor Legeforen 2013; 133 426

3. Tveitnes D, Hjetland R, Øymar K. Tolking av serologiske testar. Tidsskr Nor Legeforen 2013; 133: 826.

4. Dudman SG, Vainio K. Intravenøs immunglobulinbehandling. Tidsskr Nor Legeforen 2013; 133: 826-7.

5. Gauer K, Helgestad KL, Wirsching $C$ et al. Gauer og medarbeidere svarer. Tidsskr Nor Legeforen 2013; 133: 827

Dette er en redigert versjon av debatten, publisert først på nett 24.6.2013. http://tidsskriftet.no/article/2975319

\section{Haug svarer:}

Per Bjark mener at Tidsskriftet bør trekke tilbake en artikkel i spalten «Noe å lære av» (1) og ledsagende kommentar (2). I kasuistikken beskrives en pasient med en sjelden diagnose. Nye prøver tatt etter at artikkelen var publisert, gjorde at diagnosen måtte revurderes. Dette kommer frem i «Brev til redaktør»-spalten (3) og i rask respons-feltet under selve artikkelen. Kommentarene vil følge artikkelen både i PubMed og på våre nettsider.

En slik revurdering av diagnosen oppfatter vi ikke som grunn til å trekke tilbake artikkelen. Tvert i mot er det mye god læring $\mathrm{i}$ en åpen, faglig diskusjon om en sjelden diagnose. Tidsskriftet har ved noen anledninger trukket tilbake artikler, og vi retter oss i slike tilfeller etter internasjonale, publiseringsetiske retningslinjer (4). Rutiner for tilbaketrekking beskrives for øvrig i forfatterveiledningen (5).

\section{Charlotte Haug}

charlotte.haug@legeforeningen.no

Charlotte Haug (f. 1959) er redaktør i Tidsskrift for Den norske legeforening. Ingen oppgitte interessekonflikter.
Litteratur

1. Gauer K, Helgestad K-I, Wirsching $C$ et al. En tenåring med smerter, dobbeltsyn og ustø gange. Tidsskr Nor Legeforen 2013; 133: 422-5.

2. Ljøstad U, Mygland Å. Et virus på fremmarsj. Tidsskr Nor Legeforen 2013; 133: 426.

3. Gauer K, Helgestad K-I, Wirsching $C$ et al. K. Gauer og medarbeidere svarer. Tidsskr Nor Legeforen 2013; 133: 827.

4. www.icmje.org/publishing_2corrections.html

5. http://tidsskriftet.no/Innhold/Forfatterveiledningen/Etikk-og-jus/ Tilbaketrekking-retraction

Dette er en redigert versjon av debatten, publisert på nett 2.7.2013.

http://tidsskriftet.no/artcle/2975319

\section{Mangelfull korreksjon av feil}

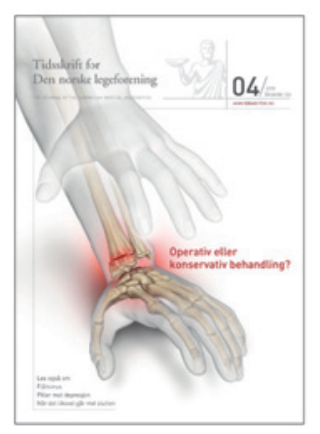

I nr. 4/2013 publiserte Tidsskriftet en «Noe å lære av»-artikkel om et barn med alvorlige nevrologiske symptomer (1). Konklusjonen i artikkelen var at barnet hadde skogflåttencefalitt (TBE) diagnostiert på bakgrunn av titerstigning av TBEIgG $i$ to påfølgende tester. I artikkelen kom det frem at barnet hadde fått behandling med intravenøs immunoglobulin mellom de diagnostiske testene. I et rask respons-innlegg påpekte vi at preparater med intravenøs immunoglobulin ofte inneholder TBE-IgG, og vi stilte spørsmål om at passivt overført TBE-IgG hadde medført den påviste titerstigningen (2). I så tilfelle ville denne være forbigående. Mistanken ble bekreftet, da forfatterne etter ny testing av barnets serum opplyste at ny TBE-IgG- test var negativ. I «Brev til redaktøren»-spalten konkluderer så forfatterne med at de ikke kan underbygge noen av differensialdiagnosene i artikkelen med solide serologiske prøver (3).

Jeg oppdaget tilfeldig at Per Bjark i et rask respons- innlegg datert 24.6.2013 har krevd at artikkelen med tilhørende relatert artikkel Et virus på frammarsj trekkes $(1,4)$. Han begrunner dette med at diagnosen ikke er holdbar. Han finner mangler i artiklene og hevder at Tidsskriftet har sviktet i kvalitetssikringen. Redaktøren avviser kravet $i$ et svar i form av rask respons-innlegg datert 2.7.2013. Ingen av disse to innleggene er publisert i papirutgaven av Tidsskriftet.

Ifølge Tidsskriftets forfatterveiledning skal artikkeltypen «Noe å lære av» presentere kasuistikker med mål om at leseren skal lære om tilstanden den aktuelle pasienten viser seg å ha. En ærlig feil «honest error» - (5) i utredningsprosessen i den aktuelle kasuistikken hadde i dette tilfellet gitt en konklusiv diagnose på sviktende grunnlag. Derav vet man ikke hvilken tilstand barnet hadde. Artikkelen må derfor korrigeres.

Tidsskriftet har valgt å synliggjøre feilen ved å publisere rask respons-innleggene sammen med det endelige svaret fra forfatterne som vedlegg i form av brev til redaktøren. Men slik artikkelen i dag fremstår, er faktafeil ikke korrigert.

Jeg mener derfor det er nødvendig at Tidsskriftet formulerer en rettelse, slik at enhver leser som går inn i artiklene, straks forstår hvilke deler av innholdet som ikke lenger har gyldighet. Retningslinjene til ICMJE - den internasjonale sammenslutningen av redaktører i medisinske tidsskrifter - for «Correction and version control» bør kunne tas i bruk her (5).

Til slutt: Da denne artikkelen ble publisert, førte den til overskrifter på Tidsskriftets hjemmeside og deretter i nasjonale medier. Kasuistikken hadde ikke bare fakta om en diagnose, men hadde også innhold av en «kasusrapport» om det første norske tilfellet av TBE-virus øst for Oslo. Dette kan ha store folkehelsekonsekvenser, bl.a. i form av råd om vaksinering, som forfatterne også skriver. Er det også behov for et offentlig dementi som rydder opp i mulig forvirring?

\section{Dag Tveitnes}

dag.tveitnes@sus.no 